might be confined to limited regions of the genome, though Grafen thinks that our heresy did not go far enough, because we seemed to assume that any form of directed mutation has to start with random changes, and so we were still neo-darwinists at heart.

This letter is primarily a response to our critics. Several commentators, however, have written to say that our experiments have tended to conform their own beliefs and interested readers should turn to their papers $^{7-110}$ for the details.

We should end with one last thought. We now know that, in the processing of biological information, almost anything is possible. Sequences are spliced, rearranged, cast aside, resurrected, and to a limited extent may even be invented when the need arises, and so it should not be difficult for an organism to devise a way of testing phenotype before adopting any new genotype. It therefore seems almost perverse to maintain, as a matter of principle, that such a mechanism has never evolved.

Harvard School of Public Health,

JoHn CAIRns Boston, Massachusetts 02115, USA

1. Cairns. J. Nature 289. 353-357 (1981).

2. Cairns, J., Overbaugh. J. \& Miller. S. Nature 335. 142 145 (1988).

3. Partridge, L. \& Morgan. M.J. Nature 336, 22 (1988).

4. Hall, B.G. Genetics (in the press).

5. Benson, S. A. Nuture 336. 21-2(1988).

6 Stahl. F.W. Nature 35, 112-113(1988)

7. Wright, B.E. C.r. Trav. Lab. Carlsbery Ser. Phvsiol. Wright, B.E. C.r.
25. 173-211(1953).

Fitch, W.M. Evolution 36. 1133-1143 (1982)

9. Shapiro. J.A. Mol. gen. Genet. 194.79-90 (1988)

10. Opadia-Kadima, G.Z.J. theor. Biol. 124, 127.135 (1987).

\section{Calcium channels}

SIR-In a recent News and Views article, Rink discussed' 'real' receptor-operated calcium channels (ROCCs) on the basis of data demonstrating single $\mathrm{Ba}^{2+}$-selective channels obtained by incorporating membrane vesicles from thrombin-stimulated platelets into planar bilayers'. It is not clear from the experiments described ${ }^{2}$ whether the channels studied are derived from the plasma membrane, and no direct link has been established between agonist-receptor interaction and channel opening. It may therefore be premature to claim that an ROCC has been found.

It would be helpful if a distinction could be maintained not only between voltagesensitive and insensitive $\mathrm{Ca}^{2+}$ channels, but also between activation of cellular $\mathrm{Ca}^{2+}$ entry mediated by second messengers (such as inositol-1,4,5-trisphosphate $\left(\operatorname{Ins}(1,4,5) \mathrm{P}_{3}\right) /$ inositol-1,3,4,5-tetrakisphosphate (Ins $\left.(1,3,4,5) \mathrm{P}_{4}\right)$, refs 3,4$)$ and direct or $\mathrm{G}$-protein-linked $\mathrm{Ca}^{2+}$ channel opening ${ }^{5.6}$. The former could be called second-messenger-operated calcium channels (SMOCCs) and the term ROCC should be reserved for the latter category.

It is possible to have a 'proper' voltagegated $\mathrm{Ca}^{2+}$ channel operating as an
SMOCC. In insulin-secreting cells, carbohydrate stimulation depolarizes the cell membrane and opens voltage-gated $\mathrm{Ca}^{2+}$ channels of the ' $\mathrm{L}$ ' type, but the small depolarization cannot by itself activate these channels without additional second messenger-mediated modulation, probably resulting from metabolic generation of diacylglycerol ${ }^{7}$.

Rink claims', referring to the recently published work of Penner et al. (ref. 8), that the role of Ins $(1,3,4,5) \mathrm{P}$ in the control of $\mathrm{Ca}^{2+}$ entry remains controversial. But the interesting experiments of Penner et al. were not designed for a critical test of the hypothesis that a combined action of Ins $(1,4,5) \mathrm{P}_{3}$ and $\operatorname{Ins}(1,3,4,5) \mathrm{P}_{4}$ is needed for $\mathrm{Ca}^{2+}$ uptake ${ }^{+.9}$, and the authors point out that their results cannot exclude a role for $\operatorname{Ins}(1,3,4,5) \mathrm{P}_{4}$. A test of the Ins $(1,4,5) \mathrm{P}_{3} / \operatorname{Ins}(1,3,4,5) \mathrm{P}_{+}$hypothesis requires a preparation such as the one we have used ${ }^{+}$, in which agonists consistently evoke $\mathrm{Ca}^{2+}$ influx and in which the same single cells can be internally perfused with both control and test solutions.

There is now clear evidence for voltagesensitive as well as voltage-insensitive $\mathrm{Ca}^{2+}$ channels. Both types can be controlled by receptor-activation directly, via G-proteins, or indirectly, via second messengers such as inositol polyphosphates or diacylglycerol. The demonstration that one of many possible $\mathrm{Ca}^{2+}$-gating mechanisms is absent in one cell type cannot, of course, be taken as evidence against a particular mode of operation found in another system.

O. H. Petersen

The Physiological Laboratory, University of Liverpool, PO Box 147 , Liverpool L69 $3 B X, U K$

1. Rink. T.J. Nature 334, 649-650)(1988)

Zschauer. A., Van Breemen. C.. Buhler. F.R. \& Nelson. M.T. Nature 334. 7(03-705 (1988)

Berridge. M.J. ISI Atlas of Science: Pharmacolon. 1.91 (1987) 4. Morris A.P. Gallacher. D.V. Irvine, R.F. \& Petersen. O. Horris. A.P. Gathe $330,655(1987)$

Benham. C.D.\& Tsien. R.W. Nature 328. 275-278 (1987).

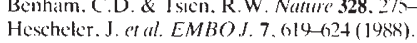

Petersen. O.H. ISI Atlas of Science: Biochemistry 1. 1+t 149 (1988).

Penner. R., Matthews, G. \& Neher. E. Nature 334. 499 (19)88) 9. Fink. L.A. \& Kaczmarek. L.K. Trends newrosci. 11. 33.8 $339(1988)$.

\section{Glucose transport}

SIR-Insulin is known to stimulate the production of diacylglycerol after binding to membrane receptors, and Strålfors has now shown' that exogenous diacylglycerols mimic insulin in stimulating glucose uptake into adipocytes. Based on this finding, he postulates that endogenous diacylglycerol mediates the effect of insulin on glucose transport. An important prediction of this hypothesis is that treatments which prevent the production of, or neutralize, diacylglycerol in the plasma membrane should be capable of blocking insulin-mediated glucose uptake. We believe that data published by $\mathrm{us}^{2-1}$ sup- port this prediction, thereby lending credence to Strålfors' hypothesis.

In our studies, we examined the effect of the cyclic polycationic decapeptide polymyxin B on various actions of insulin. In our first experiments ${ }^{2}$, we found that polymyxin B prevents insulin-induced hypoglycaemia in experimental animals. Subsequently, we observed that this compound blocks insulin-mediated 2-deoxyglucose uptake in rat adipocytes. Furthermore, we found ${ }^{3}$ that polymyxin B inhibits insulin-dependent glucose transport without affecting insulin binding to the receptor or altering the ability of insulin to either induce receptor autophosphorylation or activate receptor kinase activity. Other insulin-dependent actions, such as inhibition of lipolysis in adipocytes, synthesis of DNA in muscle cells or activation of glycogen synthase in mouse skeletal muscle are not affected by polymyxin ${ }^{3,4}$.

Previous work had demonstrated that polymyxin B binds electrostatically to acidic phospholipids in membranes, and it is possible, therefore, that the inhibitory effect of polymyxin B on insulin-stimulated glucose transport reported by us $^{+}$is due to just such a peptide-phospholipid interaction, leading to neutralization of a membrane phospholipid. Indeed, acetylation or succinylation of the five amino groups of polymyxin B prevents both binding of the peptide to membrane phospholipids as well as its ability to block insulin action". Thus our observations suggest the existence of a polymyxin B-sensitive membrane phospholipid that functions in a highly specific manner in the mechanism that mediates the effect of insulin on glucose transport. This phospholipid may be a diacylglycerol, as suggested by Strålfors.

Center for Studies in Behavioral SHIMON AMIR

Neurobiology.

Concordia University,

Montreal, Quebec, H3G 1M8, Canada YORAM SHeCHTER

Department of Hormone Research,

The Weizmann Institute of Science, Rehovot, Israel

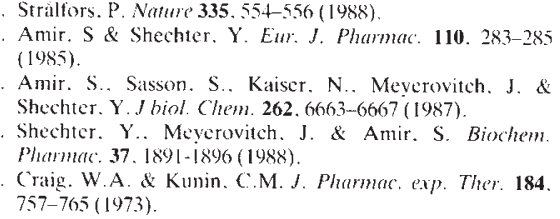

\section{Scientific Correspondence}

Scientific Correspondence is intended to provide a forum in which readers may raise points of a scientific character. They need not arise out of anything published in Nature. In any case, priority will be given to letters of less than 500 words and five references. 